\title{
Equine proliferatieve enteropathie veroorzaakt door Lawsonia intracellularis: geen zeldzame aandoening meer!
}

\author{
K. Vyncke, P. Deprez, K. Verryken, L. Lefère, S. Torfs, G. van Loon \\ Vakgroep Inwendige Ziekten Grote Huisdieren, Faculteit Diergeneeskunde, Universiteit Gent, \\ Salisburylaan 133, B-9820 Merelbeke \\ Kris.Vyncke@ugent.be
}

\begin{abstract}
SAMENVATTING
Equine proliferatieve enteropathie, veroorzaakt door Lawsonia intracellularis, werd pas op het einde van de vorige eeuw voor het eerst beschreven en werd initieel beschouwd als een sporadisch voorkomende aandoening, maar ze komt tegenwoordig steeds vaker voor. Als kenmerkende klinische symptomen worden vermageren, lethargie, ventraal oedeem, koorts en eventueel diarree en koliek vermeld bij veulens van twee tot acht maanden oud. Bij bloedonderzoek valt vooral een uitgesproken hypoalbuminemie op. De diagnose kan gesteld worden aan de hand van serologie en een PCR-analyse van de mest. Sinds een paar jaar wordt het duidelijk dat een zeer groot deel van onze veulens en paarden seropositief is voor Lawsonia, hetgeen wijst op een sterke verspreiding van het agens in de omgeving. Daarom moet equine proliferatieve enteropathie (EPE) momenteel als een belangrijke differentiaal diagnostische mogelijkheid aanzien worden bij veulens met gewichtsverlies of andere digestieve klachten.
\end{abstract}

\section{INLEIDING}

Equine proliferatieve enteropathie (EPE) wordt de laatste jaren steeds meer gediagnosticeerd bij veulens van enkele maanden oud. Deze aandoening wordt ook omschreven als proliferatieve enteritis, proliferatieve ileitis of intestinale adenomatosis naar analogie met de vergelijkbare aandoening bij varkens. Klinisch wordt de aandoening vooral gekenmerkt door vermageren, lethargie, ventraal oedeem, koorts en eventueel diarree en koliek (Lavoie et al., 2000; McKenzie, 2009; Kranenburg et al., 2010). Proliferatieve enteropathie bij paarden werd als klinische entiteit voor de eerste maal beschreven in 1982 door Duhamel en Wheeldon. De kiem die verantwoordelijk is voor deze aandoening, met name Lawsonia intracellularis, werd echter pas in 1995 bij het varken geïdentificeerd. McOrist et al. (1995) en Williams et al. (1996) waren de eersten om Lawsonia aan te tonen bij een klinisch geval van EPE. Momenteel kent de aandoening bijna een wereldwijde distributie en er werden klinische gevallen beschreven in de Verenigde Staten (Williams et al., 1996; Frank et al., 1998; Brees et al., 1999; Lavoie et al., 2000; Schumacher et al., 2000; Sampieri et al., 2006), Canada (Lavoie et al., 2000; Bihr, 2003; Dauvillier et al., 2006), Australië (McClintock en Collins, 2004), Engeland (Sainty, 2002), België (Deprez et al., 2005), Zwitserland (Wuersch et al., 2006) en Nederland (Butler et al., 2006). Meestal gaat het om geïsoleerde gevallen van EPE, alhoewel ook groepsuitbraken beschreven worden (Lavoie et al., 2000; Frazer, 2008; McGurrin et al., 2007; Merlo et al., 2009). Aangezien EPE ook in België aan belang lijkt toe te nemen, wordt in dit artikel een overzicht gegeven van de recente literatuurgegevens over EPE, aangevuld met een bespreking van zes klinische gevallen.

\section{ETIOLOGIE EN PATHOGENESE}

Alhoewel sinds meerdere jaren bekend is dat equine proliferatieve enteropathie veroorzaakt wordt door de gramnegatieve obligaat intracellulaire bacterie Lawsonia intracellularis, is de exacte bron van infectie bij paarden op dit moment nog steeds niet helemaal duidelijk. Gezien de hoge prevalentie (90\%) van Lawsonia intracellularis op varkensbedrijven werd er in eerste instantie aangenomen dat contact met varkens en/of varkensmest een belangrijke besmettingsbron zou zijn, temeer daar veulens met porciene isolaten kunnen besmet worden (Al-Ghamdi et al., 2002). Uit recent onderzoek is echter gebleken dat contact met varkensmest geen significante invloed heeft op het aantal seropositieve dieren (Kranenburg et al., 2010). Waarschijnlijk zijn andere wilde of gedomesticeerde gastheren, zoals vossen, honden, konijnen, ratten of vogels, een bron van infectie (Pusterla et al., 2008). De infectie gebeurt zoals bij varkens langs de oro-fecale route via opname van geïnfecteerd voeder of drinkwater. Bij varkens bedraagt de incubatieperiode na blootstelling aan de kiem twee tot drie weken (Smith en McOrist, 1997). Uit onderzoek blijkt dat de lengte van de incubatieperiode bij veulens vergelijkbaar is met deze bij varkens (Pusterla et al., 2010). De kiem hecht zich na opname vast aan de enterocyten en dit voornamelijk ter hoogte van het ileum. Lawsonia intracellularis vertoont hierbij een uitgesproken tropisme voor de epitheliale cryptcellen. Met behulp van een kortlevende vacuole wordt de bacterie door fagocytose opgenomen in deze cryptcellen. Door deze manier van opname in de cel wordt voorkomen dat de kiem beschadigd wordt door de fagolysosomale fusie (Smith en Lawson, 2001). Na opname verblijft de kiem vrij in het apicale cytoplasma en gaat zich in associatie met de mitochondriën vermenigvuldigen. De geïnfecteerde cryptcellen onder- 
gaan een uitgesproken mitotische deling, hetgeen leidt tot de ontwikkeling van ongedifferentieerde cryptcellen zonder functionele brush border. Hierdoor ontstaan er een hyperplasie en verdikking van de intestinale mucosa en een verminderde darmabsorptiecapaciteit (Figuur 1). De uitscheiding van de kiem treedt op wanneer de geïnfecteerde cellen worden afgestoten naar het intestinale lumen (Lawson en Gebhart, 2000). Pusterla et al. (2010) hebben pasgespeende veulens experimenteel geïnoculeerd met Lawsonia intracellularis en detecteerden een fecale uitscheiding van de kiem beginnend tussen twaalf en achttien dagen na de infectie en met een gemiddelde uitscheidingsduur van zeven tot eenentwintig dagen. In de omgeving blijft de kiem slechts kort infectieus: Collins et al. (2000) geven een overlevingsduur van ongeveer twee weken aan bij een omgevingstemperatuur van 5 tot $15^{\circ} \mathrm{C}$.

\section{EPIDEMIOLOGIE}

Proliferatieve enteropathie is het best bekend bij varkens en werd voor het eerst beschreven als intestinale adenomatosis in 1931 (Biester en Schwartze, 1931). Porciene proliferatieve enteropathie (PPE) is van groot economisch belang binnen de varkensindustrie en kent een wereldwijde distributie. Bij het varken zijn meerdere ziektebeelden mogelijk, waarbij een subklinische infectie of diarree en een verminderde groei bij biggen en vleesvarkens het meest voorkomende klinische beeld zijn. Daarnaast kan bij oudere vleesvarkens ook een acute vorm voorkomen, gekenmerkt door bloederige diarree en acute sterfte. Men schat dat PPE in Europa een prevalentie van 90\% kent (McOrist, 1995). Vrij vlug na de identificatie bij het varken werd Lawsonia intracellularis ook bij andere diersoorten, zoals paarden, hamsters, ratten, schapen, reeën, honden, vossen, fretten, cavia's, apen en struisvogels, aangetoond als een enteropathogene kiem (Drolet et al., 1996; Cooper en Gebhart, 1998; Klein et al., 1999). Moleculair onderzoek van Lawsonia intracellularis isolaten afkomstig uit intestinale letsels bij verschillende diersoorten toonde aan dat er 98\% homologie bestaat met het 16S rRNA-gen van Lawsoniaisolaten bij varkens (Cooper en Gebhart, 1998). Hoewel deze bacterie voorkomt bij een uitgebreide groep van diersoorten en zelfs bij primaten, zijn er tot op heden geen indicaties dat Lawsonia een zoonotisch agens is (Pusterla en Gebhart, 2009).

Momenteel komen er meer en meer gegevens beschikbaar over de prevalentie van Lawsonia intracellularis bij paarden. Pusterla et al. (2009a) deden een serologische studie met de immunoperoxidase monolayer assay (IPMA) test bij merries op een aangetast bedrijf en vonden ongeveer $54 \%$ seropositieve merries op het moment van de partus. Breuer et al. (2010) deden een serologische studie bij een beperkt aantal gehospitaliseerde en gezonde veulens in Duitsland en vonden een seroprevalentie van respectievelijk $39 \%$ en $29 \%$ bij deze steekproef, maar hierbij werd geen onderscheid gemaakt tussen colostrale en actief verworven anti-

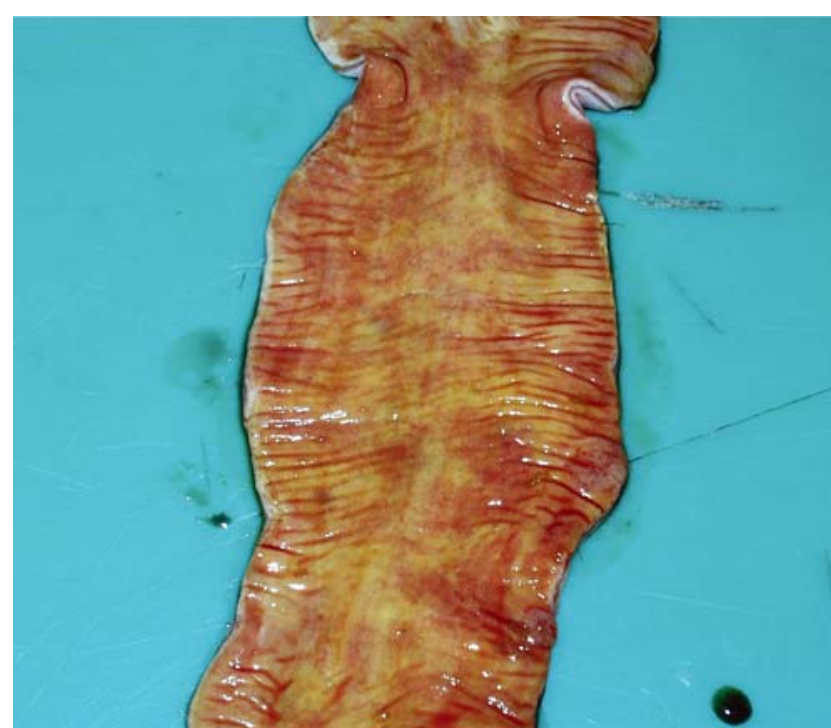

Figuur 1. Verdikte wand van de dunne darm bij een veulen met EPE. Door de hyperplasie en verdikking van de intestinale mucosa ontstaan er plooien in de darmwand.

stoffen. In 2011 deden Breuer et al. een bijkomend serologisch onderzoek op twee stoeterijen waarbij alle merries positief testten. Kranenburg et al. (2011) voerden een uitgebreide studie uit met als doel de seroprevalentie van Lawsonia intracellularis bij paarden in Nederland te onderzoeken. Hiervoor werden er bloedmonsters genomen van gezonde veulens voor en na het spenen, van jaarlingen en van volwassen paarden op diverse locaties verspreid over Nederland. Deze bloedmonsters werden door middel van een blocking ELISA onderzocht op de aanwezigheid van specifieke antilichamen tegen Lawsonia intracellularis. De resultaten van dit onderzoek tonen een significante toename aan van de hoeveelheid antilichamen tegen Lawsonia intracellularis met een toenemende leeftijd: de seroprevalentie steeg van $15 \%$ vóór het spenen tot $23 \%$ na het spenen. Bij jaarlingen had $89 \%$ antilichamen tegen Lawsonia en bij volwassen dieren ouder dan twee jaar zag men een seroprevalentie van $99 \%$. Er werd geen significant verschil in aantal positieve dieren gevonden tussen paarden die op stal stonden en paarden die op de weide gehouden werden. Vergelijkbare resultaten werden bekomen door Pusterla et al. in 2009. Deze auteurs konden op een endemisch aangetast bedrijf symptoomloze seroconversie aantonen bij ongeveer een derde van de veulens tussen een leeftijd van twee en zeven maanden.

De bovenstaande serologische onderzoeken tonen aan dat contact met Lawsonia intracellularis bij paarden meer voorkomt dan vroeger vermoed werd en dat seropositiviteit niet direct gecorreleerd is met de klinische symptomen. Het grootste deel van de Lawsonia intracellularis infecties zijn bijgevolg subklinische infecties (Pusterla et al., 2008; Pusterla en Gebhart, 2009; Kranenburg et al., 2011). Een vergelijkbare toestand is aanwezig bij de hond. Ook daar worden bij symptoomloze dieren hoge seroprevalenties gevonden (Klimes et al., 2007). 
De hoge seroprevalentie bij volwassen dieren suggereert een regelmatige blootstelling aan Lawsonia intracellularis of een langdurige persistentie van de antilichamen. Volgens de resultaten van Pusterla et al. (2011) zou een regelmatige blootstelling aan antigeen de belangrijkste oorzaak van deze hoge seroprevalentie zijn. De hoge graad van seropositiviteit bij volwassen paarden kan daarnaast ook verklaren waarom jonge, zogende veulens zelden klinische symptomen van EPE vertonen. Via het colostrum worden antistoffen doorgegeven aan het veulen en dit zorgt voor een passieve bescherming van het veulen. Deze maternale antistoffen kunnen aangetoond worden in het serum tot een leeftijd van één tot vier maanden (Pusterla et al., 2009a; Breuer et al., 2011; Kranenburg et al., 2011).

\section{KLINISCHE SYMPTOMEN}

Proliferatieve enteropathie komt voornamelijk voor bij veulens tussen twee en acht maanden oud. In deze periode treedt er een progressieve daling van de hoeveelheid maternale antistoffen op, wat de dieren vatbaarder kan maken voor infectie. Frazer (2008) suggereerde nog andere mogelijke predisponerende factoren voor EPE bij jonge veulens, zoals spenen, transport en hergroepering van de dieren, vaccineren, training, ontworming en parasitaire infecties.

De meest voorkomende symptomen bij klinisch aangetaste dieren zijn lethargie, anorexie, ventraal oedeem, koorts, diarree en koliek. Veulens met EPE vertonen vaak ook bijkomende afwijkingen, zoals luchtweginfecties, dermatitis, maagulcera of maagdarmnematoden (Frazer, 2008; Lavoie et al., 2000; Pusterla en Gebhart, 2009). Het verloop van de aandoening kan geleidelijk over een aantal dagen gaan of hyperacuut zijn met erge dehydratatie, shocksymptomen of zelfs therapieresistente kolieksymptomen (Frazer, 2008).

Bij bloedonderzoek is de meest voorkomende abnormaliteit een uitgesproken hypoproteïnemie als gevolg van een hypoalbuminemie. De combinatie van

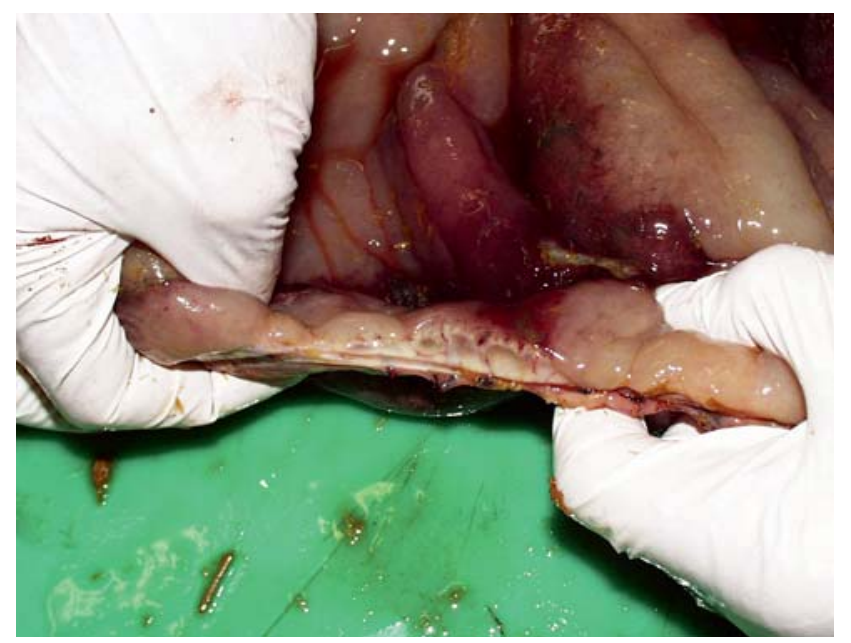

Figuur 2. Doorsnede van een verdikte en oedemateuze wand van de dunne darm bij een veulen met EPE. De normale wanddikte van dunne darmen bedraagt $\leq 3 \mathrm{~mm}$. verminderde voedselopname, malabsorptie en het verlies van eiwitten doorheen de darmwand (protein losing enteropathy) zijn verantwoordelijk voor het lage eiwitgehalte in het bloed (Wong et al., 2009). Andere afwijkingen die kunnen voorkomen zijn anemie, leukocytose, neutropenie, hyperfibrinogenemie, hemoconcentratie en een milde stijging van de spierenzymen creatinefosfokinase (CK), aspartaat aminotransferase (AST) en lactaatdehydrogenase (LDH) (Lavoie et al., 2000; Frazer, 2008; Pusterla en Gebhart, 2009). De stijging van de spierenzymen is waarschijnlijk te wijten aan de katabole toestand waarin de veulens zich bevinden.

\section{DIAGNOSE}

Voor het stellen van de diagnose van EPE kan men verschillende methoden aanwenden. De waarschijnlijkheidsdiagnose kan men stellen op basis van de klinische symptomen in combinatie met een afwijkend bloedonderzoek, waarbij de aanwezigheid van hypoalbuminemie de meest consistente afwijking is (Frazer, 2008). Uiteraard is hypoalbuminemie niet specifiek voor EPE, aangezien ook andere ziekteprocessen, zoals colitis, parasitaire infestatie en salmonellose, eveneens hypoalbuminemie kunnen veroorzaken bij veulens (Page et al., 2011). Echografisch onderzoek van het abdomen kan helpen bij het stellen van de diagnose. Bij sommige dieren kan de verdikking van de wand van de dunne darmen (adenomatosis) echografisch waargenomen worden. De wanddikte van de dunne darmen is onder normale omstandigheden ongeveer $3 \mathrm{~mm}$ (Reef, 1998) maar door de hyperplasie en hyperproliferatie kan dit toenemen (Figuur 2 en 3). Een normale darmwanddikte sluit EPE echter niet uit, aangezien er ook veulens met EPE zijn waarbij de wanddikte van de dunne darmen binnen de normale grenzen blijft (Frazer, 2008; Page et al., 2011).

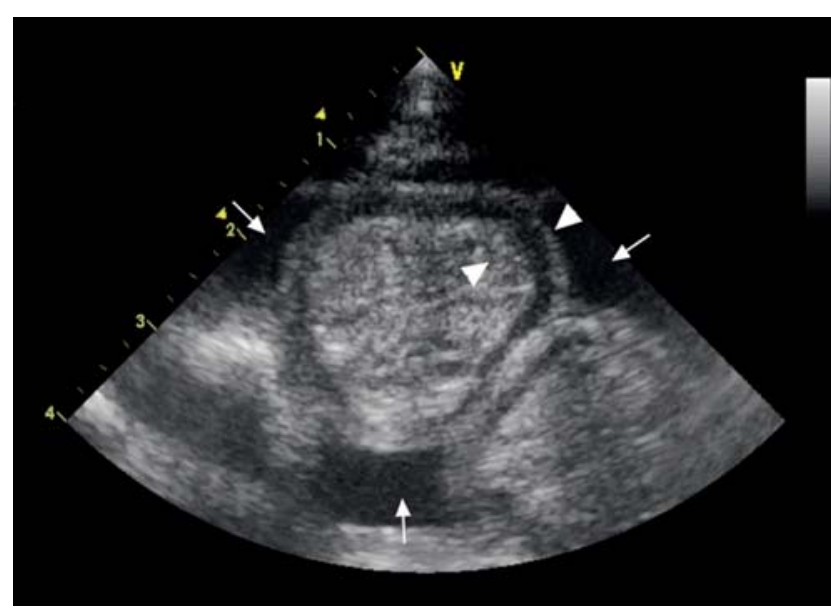

Figuur 3. Echografisch beeld van een verdikte darmwand bij een zeven maanden oud veulen met equine proliferatieve enteropathie (EPE). De mucosa is sterk verdikt en vertoont plooien, waardoor het lumen een stervormig uitzicht krijgt. De dikte van de wand wordt weergegeven door de pijlpunten en bedraagt $7 \mathrm{~mm}$. Rond de dunne darmen is er vrij buikvocht aanwezig (pijltjes). 
De meer specifieke diagnostische testen voor het stellen van de ante mortem diagnose omvatten serologie en PCR-analyse. Er zijn meerdere serologische technieken ter beschikking voor het aantonen van IgGantilichamen tegenover Lawsonia intracellularis. Bij varkens zijn immunofluorescentie (IFAT) en immunoperoxidase monolayer assay (IPMA) analysemethoden met een hoge specificiteit en sensitiviteit (Guedes et al., 2002). Bij de meeste studies met paarden wordt er gebruikt gemaakt van de IPMA-methode (Pusterla et al., 2009a). Een antistoftiter van meer dan 60 wordt hierbij beschouwd als een vrij betrouwbare indicatie voor een recente of actieve infectie met Lawsonia intracellularis. De test heeft bij gebruik bij varkens een sensitiviteit van $100 \%$ en een specificiteit van $90 \%$. Valspositieve resultaten kunnen dus voorkomen. De IPMA-test is momenteel nog niet gevalideerd voor het opsporen van antilichamen tegen Lawsonia bij paarden (Frazer, 2008). Sinds kort wordt er ook gebruik gemakt van een competitieve blocking ELISA-test (Enterisol Ileitis Elisa, Boehringer Ingelheim) die commercieel beschikbaar is voor varkens (Breuer et al., 2010; Kranenburg et al., 2011). Deze ELISA-technologie laat toe om grote aantallen bloedmonsters te analyseren op een relatief korte tijd. Een nadeel is dat men enkel een semikwantitatief resultaat met deze test verkrijgt en weinig informatie over de hoogte van de antistoffentiter. Een positieve test kan bijgevolg zowel wijzen op een recent als een vroeger contact met de kiem. Veulens kunnen na contact immers gedurende zes maanden seropositief blijven voor Lawsonia intracellularis (Dauvillier et al., 2006).

Voor het aantonen van een acute infectie met Lawsonia intracellularis kan gebruik gemaakt worden van een PCR-analyse op mestmonsters. Hiermee wordt het aspA (aspartaat ammoniumlyase) gen van Lawsonia intracellularis opgespoord. Een PCR-analyse op mestmonsters is zeer specifiek maar heeft een variabele sensitiviteit. De intermitterende uitscheiding van de kiem en de aanwezigheid van potentiële inhiberende componenten in de mest kunnen aangehaald worden als mogelijke oorzaken voor valsnegatieve resultaten (Lavoie et al., 2000; Page et al., 2011). Ook valspositieve resultaten kunnen voorkomen omdat ook afgestorven kiemen of een passieve passage van Lawsonia in de mest kan aangetoond worden met PCR. Voor het stellen van de ante mortem diagnose van EPE combineert men bijgevolg het beste serologie en PCR-analyse, aangevuld met de gegevens van het klinisch onderzoek en het bloedonderzoek (hypoalbuminemie). De simultane aanwezigheid van hypoalbuminemie en een positieve PCR is sterk indicatief voor een acute actieve infectie.

De post mortem diagnose kan gebeuren aan de hand van de macroscopische letsels, maar een histologische bevestiging is noodzakelijk. De proliferatie van de enterocyten kan aangetoond worden met de klassieke histologie met een hematoxyline en eosinekleuring. Voor het in beeld brengen van de intracellulaire kiem in het apicale cytoplasma kan een Warthin-Starry zilverkleuring of een immunohistochemische kleuring aangewend worden.

\section{BEHANDELING}

De behandeling van EPE bestaat uit het gebruik van antimicrobiële middelen al dan niet gecombineerd met een ondersteunende therapie. Bij de behandeling van Lawsonia intracellularis gaat de voorkeur uit naar producten met een hoge vetoplosbaarheid, zoals macroliden, rifampicine en tetracyclines. Deze antibiotica zijn in staat therapeutische concentraties te bereiken in het cytoplasma van de geïnfecteerde enterocyten. Vaak wordt er gebruik gemaakt van $25 \mathrm{mg} / \mathrm{kg}$ erytromycine oraal, drie keer per dag, eventueel in combinatie met 7 $\mathrm{mg} / \mathrm{kg}$ rifampicine oraal, twee keer per dag, en dit gedurende drie tot vier weken (Lavoie et al., 2000; Pusterla en Gebhart, 2009). Erytromycine heeft als voordeel dat het een lage MIC-waarde $(\leq 1 \mu \mathrm{g} / \mathrm{ml})$ bezit met betrekking tot Lawsonia intracellularis (McOrist et al., 1995). Andere voordelen van deze therapie zijn de synergistische werking tussen beide antibiotica, de goede intracellulaire accumulatie van de producten en de vertrouwdheid van paardenpractici met deze combinatie uitgaande van het gebruik bij Rhodococcus infecties (McClintock en Collins, 2004). Er zijn ook enkele nadelen verbonden aan het gebruik van erytromycine. Erytromycine is een motilinereceptor agonist en dit kan leiden tot het ontwikkelen van diarree (McKenzie, 2009). Daarnaast kan erytromycine een daling van de thermoregulerende respons induceren, hetgeen hyperthermie kan veroorzaken bij hogere omgevingstemperaturen. Gezien de neveneffecten van de erytromycinetherapie en de nood aan multipele doseringen per dag groeit de interesse voor het gebruik van andere antibiotica voor de behandeling van EPE. Studies tonen aan dat ook andere macroliden, zoals azitromycine $(10 \mathrm{mg} / \mathrm{kg}$ oraal, sid) en claritromycine $(7,5 \mathrm{mg} / \mathrm{kg}$ oraal, bid) succesvol blijken te zijn voor de behandeling van Lawsonia intracellularis (Atherton en McKenzie, 2006). Ook het gebruik van tetracyclines bij de behandeling van EPE lijkt succesvol te zijn. Tetracyclines hebben een goede penetratie en accumulatie in het cytoplasma én vertonen lage MIC-waarden ten opzichte van Lawsonia intracellularis, met name $\leq 1$ $\mu \mathrm{g} / \mathrm{ml}$ voor chloortetracycline (McOrist et al., 1995). Zowel de orale toediening van doxycycline $(10 \mathrm{mg} / \mathrm{kg}$ bid) als de parenterale toediening van oxytetracycline $(6,6 \mathrm{mg} / \mathrm{kg}$ bid) blijkt effectief te zijn (Atherton en McKenzie, 2006; Sampieri et al., 2006). Met het gebruik van fluoroquinoles kunnen eveneens hoge intracytoplasmatische concentraties bekomen worden, maar het gebruik ervan wordt afgeraden bij opgroeiende dieren om kraakbeenschade te voorkomen (McKenzie, 2009).

Samengevat kan gesteld worden dat momenteel een behandelingsduur van drie tot vier weken aanbevolen wordt, hetzij met een combinatie van macroliden en rifampicine, hetzij met tetracyclines. Op dit moment zijn er nog onvoldoende vergelijkende studies gebeurd om een duidelijke voorkeur voor de ene of andere behandeling aan te geven.

Bijkomende ondersteunende therapie, indien aangewezen, kan bestaan uit plasmatransfusie, vochtthera- 
pie, parenterale voeding en anti-ulcertherapie. Doorgaans ziet men na het opstarten van de therapie een snelle verbetering van de klinische symptomen, maar het duurt wel enkele weken vooraleer de hypoproteïnemie genormaliseerd is. Een spontaan herstel na een klinische Lawsonia intracellularis infectie lijkt zelden voor te komen (Pusterla en Gebhart, 2009). De prognose na behandeling daarentegen is goed, alhoewel aangetaste veulens wel een groeiachterstand kunnen vertonen ten opzichte van hun leeftijdsgenoten. Dit kan gevolgen hebben voor de verkoopprijs van deze dieren. Aangetaste veulens worden als jaarlingen verkocht voor gemiddeld $68 \%$ van de verkoopprijs van vergelijkbare leeftijdsgenoten (Frazer, 2008; McKenzie, 2009).

\section{PREVENTIE}

Wegens de onzekerheid over de precieze herkomst van de infectie bij paarden, zijn er momenteel weinig concrete preventieve richtlijnen beschikbaar voor EPE. Bij varkens daarentegen zijn wel controlemaatregelen tegen Lawsonia intracellularis beschreven, zoals het gebruik van preventieve of metafylactische voedermedicatie, en sinds kort het gebruik van een commercieel levend verzwakt vaccin.

Ook bij veulens wordt er momenteel onderzoek verricht naar vaccinatie. Pusterla et al. (2009b) hebben veulens peroraal en intrarectaal gevaccineerd met een commercieel avirulent levend varkensvaccin. Vooral de intrarectale toediening bleek in staat te zijn een seroconversie en een uitscheiding van de vaccinstam te induceren. In een vergelijkbare intrarectale vaccinstudie door Nogadi et al. (2011) werd geen verschil in klinische symptomen opgemerkt tussen gevaccineerde en niet-gevaccineerde dieren, maar bij beide groepen was er een daling van de ziekteprevalentie in vergelijking met het vorige jaar. De auteurs suggereerden dat de uitscheiding van de vaccinstam door de gevaccineerde veulens op haar beurt een beschermende immuunrespons zou kunnen uitlokken bij de niet-gevaccineerde dieren in de omgeving (Nogradi et al., 2011). Ook Westhoff et al. (2010) dienden in een veiligheidsstudie het varkensvaccin peroraal toe aan jonge veulens en konden geen lokale of systemische neveneffecten waarnemen. Bijgevolg vormt het beschikbare varkensvaccin een opportuniteit voor toekomstige preventie maar het is momenteel nog onvoldoende klinisch getest voor gebruik in de praktijk. Het is daarom vooral belangrijk dat de aandoening in een vroeg stadium herkend wordt om zo een vroege en daardoor succesvolle behandeling te kunnen instellen. Verder onderzoek naar onder andere predisponerende factoren en de infectiebronnen is en blijft echter noodzakelijk om een betere preventie mogelijk te maken (Kranenburg et al., 2011). Algemene hygiënemaatregelen, zoals dieren niet op de grond voederen, zodat de kans op besmetting van het voeder zou verminderen, kunnen al een stap in de goede richting zijn.

\section{BESPREKING KLINISCHE GEVALLEN}

In België werd het eerste klinische geval van EPE beschreven in 2005 (Deprez et al., 2005). Sindsdien worden er in België meer en meer klinische gevallen gerapporteerd. Tabel 1 geeft een overzicht van de bevestigde klinische gevallen die werden aangeboden in de kliniek Inwendige Ziekten van de Grote Huisdieren van de Universiteit Gent te Merelbeke in de periode 2008-2011.

Het gaat hierbij om dieren van enkele maanden tot een jaar oud, met een mediaan van zes maanden, hetgeen overeenkomt met de leeftijd in het overzicht van Frazer in 2008. De meeste dieren werden aangeboden in de periode van oktober tot november. Dit is de periode waarin de meeste veulens de gevoelige leeftijd bereiken. Ook in het overzicht van Frazer (2008) wordt

Tabel 1. Overzicht van zes bevestigde klinische gevallen van EPE aangeboden in de kliniek Inwendige Ziekten van de Grote Huisdieren (Faculteit Diergeneeskunde, UGent) in de periode 2008-2011.

\begin{tabular}{|c|c|c|c|c|c|c|c|c|}
\hline Patiënt & Geslacht & Leeftijd & Symptomen & $\begin{array}{l}\text { Totaal } \\
\text { eiwit } \\
\text { (ref. 55-75 g/L) }\end{array}$ & $\begin{array}{l}\text { Albumine } \\
\text { (ref. 30-37 g/L) }\end{array}$ & $\begin{array}{l}\text { Parasitair } \\
\text { onderzoek }\end{array}$ & $\begin{array}{l}\text { Diagnose } \\
\text { PCR }\end{array}$ & ELISA \\
\hline $\begin{array}{l}\text { Veulen } 1 \\
\text { nov '08 }\end{array}$ & merrie & 6 maanden & $\begin{array}{l}\text { koorts, verminderde } \\
\text { eetlust, suf }\end{array}$ & $32 \mathrm{~g} / \mathrm{L}$ & $13 \mathrm{~g} / \mathrm{L}$ & $\begin{array}{l}\text { Parascaris } \\
\text { EPG: } 250\end{array}$ & + & $\begin{array}{l}\text { niet } \\
\text { uitgevoerd }\end{array}$ \\
\hline $\begin{array}{l}\text { Veulen } 2 \\
\text { nov ' } 08\end{array}$ & merrie & 6 maanden & $\begin{array}{l}\text { koorts, verminderde } \\
\text { eetlust, suf, } \\
\text { waterige diarree }\end{array}$ & $<20 \mathrm{~g} / \mathrm{L}$ & $\begin{array}{l}\text { niet } \\
\text { uitgevoerd }\end{array}$ & $\begin{array}{l}\text { niet } \\
\text { uitgevoerd }\end{array}$ & + & $\begin{array}{l}\text { niet } \\
\text { uitgevoerd }\end{array}$ \\
\hline $\begin{array}{l}\text { Veulen } 3 \\
\text { nov' } 10\end{array}$ & hengst & 7 maanden & $\begin{array}{l}\text { vermageren, verminderde } \\
\text { eetlust }\end{array}$ & $29 \mathrm{~g} / \mathrm{L}$ & $10,5 \mathrm{~g} / \mathrm{L}$ & $\begin{array}{l}\text { Strongyliden } \\
\text { EPG: } 100\end{array}$ & + & + \\
\hline $\begin{array}{l}\text { Veulen } 4 \\
\text { okt'11 }\end{array}$ & merrie & 5 maanden & $\begin{array}{l}\text { koorts, verminderde } \\
\text { eetlust, suf }\end{array}$ & $29 \mathrm{~g} / \mathrm{L}$ & $10 \mathrm{~g} / \mathrm{L}$ & $\begin{array}{l}\text { Strongyliden } \\
\text { EPG: } 0\end{array}$ & + & + \\
\hline $\begin{array}{l}\text { Veulen } 5 \\
\text { okt' } 11\end{array}$ & hengst & 5 maanden & $\begin{array}{l}\text { vermageren, verminderde } \\
\text { eetlust, suf, diarree }\end{array}$ & $34 \mathrm{~g} / \mathrm{L}$ & $12 \mathrm{~g} / \mathrm{L}$ & $\begin{array}{l}\text { Strongyliden } \\
\text { EPG: } 50\end{array}$ & + & + \\
\hline $\begin{array}{l}\text { Veulen } 6 \\
\text { nov' } 11\end{array}$ & merrie & 6 maanden & $\begin{array}{l}\text { koorts, vermageren, } \\
\text { ventraal oedeem }\end{array}$ & $27 \mathrm{~g} / \mathrm{L}$ & $12 \mathrm{~g} / \mathrm{L}$ & $\begin{array}{l}\text { niet } \\
\text { uitgevoerd }\end{array}$ & + & + \\
\hline
\end{tabular}


aangegeven dat alle veulens met EPE aangeboden werden tussen augustus en januari, met een piek in november en december. Zoals reeds gebleken is uit andere overzichten werd ook hier geen geslachtspredispositie waargenomen bij de aangeboden patiënten.

De meest voorkomende symptomen waren een verminderde eetlust (5/6), lethargie $(4 / 6)$, koorts $(4 / 6)$ en vermageren (3/6). Diarree lijkt veel minder dan bij het varken een symptoom van een Lawsonia intracellularis infectie te zijn. Slechts twee van de zes veulens vertoonden diarree. Een opmerkelijk verschil met de beschrijvingen uit de literatuur is dat oedeem bij slechts één van de zes hierbovenbeschreven patiënten waargenomen werd, terwijl dit in de meeste overzichten bij meer dan de helft van de gevallen vermeld wordt. Hiervoor is niet direct een verklaring voorhanden: het eiwit- en albuminegehalte van onze patiënten was vergelijkbaar laag met hetgeen in de literatuur vermeld wordt. Ook het eerste beschreven klinische geval in België vertoonde duidelijk ventraal oedeem.

Bloedonderzoek toonde bij alle dieren een matige tot uitgesproken daling van het totaal eiwitgehalte aan met waarden die varieerden van minder dan $20 \mathrm{~g} / \mathrm{L}$ tot $34 \mathrm{~g} / \mathrm{L}$ (referentiewaarde: 55-75 g/L), waardoor hypoproteïnemie een constante bevinding bij alle patiënten was. Er werd eveneens een uitgesproken daling van het albuminegehalte waargenomen. Deze waarden varieerden van minder dan $10 \mathrm{~g} / \mathrm{L}$ tot $13 \mathrm{~g} / \mathrm{L}$ (referentiewaarde: 30 $37 \mathrm{~g} / \mathrm{L}$ ). De rest van de bloedparameters waren grotendeels normaal, tenzij wat ionaire verstoring en prerenale uremie bij de dieren die eveneens diarree vertoonden.

Aangezien ernstige parasitaire infestaties vergelijkbare symptomen kunnen veroorzaken en mogelijk predisponerend zouden kunnen zijn voor het ontstaan van klinische Lawsonia infecties bij veulens, werd er ook parasitair onderzoek uitgevoerd bij dieren die niet recentelijk ontwormd waren. Daarbij werden matige EPG-gehalten gevonden bij drie veulens (EPG tussen 50 en 100) en het parascarisonderzoek was positief bij veulen 1 . Deze parasitaire infecties waren niet van dien aard dat ze de erge graad van hypoproteïnemie konden verklaren.

Bij alle patiënten werd echografisch onderzoek van het abdomen uitgevoerd, waarbij heel specifiek naar de wanddikte van de dunne darm gekeken werd. Bij vijf van de zes patiënten werd een verdikte darmwand waargenomen $(>3 \mathrm{~mm})$, hetgeen, in combinatie met de klinische symptomen, indicatief is voor intestinale adenomatosis of EPE. De uiteindelijke diagnose werd gesteld door het PCR-onderzoek van de mest, eventueel aangevuld met serologie.

Alle dieren werden behandeld met een combinatie van claritromycine en rifampicine, enkel bij veulen 2 werd er gebruik gemaakt van doxycycline. Dieren met een parasitaire infectie werden behandeld met aangepaste antiparasitaire middelen. Bij de veulens 2, 3, 4 en 6 met een uitgesproken hypoproteïnemie werd een plasmatransfusie uitgevoerd. Op korte termijn was de prognose na behandeling goed. Enkel veulen 4 overleefde de aandoening niet. Dit Friese veulen vertoonde op lijkschouwing eerder een atypisch beeld, waarbij zo- wel in de dunne darm als in het colon letsels aangetroffen werden, gaande van een lymfoplasmocellulaire enteritis tot necrotiserende letsels. Vergelijkbare histologische letsels werden vermeld door van den Wollenberg et al. (2011) bij een Lawsonia uitbraak bij Friese veulens. Ook Ellis et al. (2011) beschreven uitgebreide ulceratieve letsels met een fibrineus tot necrotisch beleg in het jejunum van een aangetast veulen. Daarnaast vermeldde zowel van den Wollenberg et al. (2011) als Frazer (2008) letsels als gevolg van trombi ter hoogte van verschillende organen. Dit toont aan dat zelfs de diagnose na autopsie niet altijd eenduidig is en dat Lawsonia intracellularis infecties bij veulens een variabel en soms vlug fataal verloop kennen.

\section{CONCLUSIE}

Equine proliferatieve enteropathie veroorzaakt door Lawsonia intracellularis is een aandoening die steeds vaker gerapporteerd wordt bij veulens en ook in België als een endemische infectie moet aanzien worden. Klachten van vermageren, koorts, een verminderde eetlust, diarree, ventraal oedeem en koliek bij veulens tussen twee en acht maanden oud zijn sterk suggestief voor EPE maar kunnen ook door andere aandoeningen veroorzaakt worden. Een meer sluitende diagnostiek is bijgevolg aangewezen vooraleer specifiek tegen Lawsonia te behandelen. Een klinisch hulpmiddel hiervoor, eventueel in afwachting van de resultaten van het laboratoriumonderzoek, is echografisch onderzoek van het abdomen. Een verdikte dunne darm is hierbij sterk suggestief voor EPE. Bloedonderzoek is eveneens nuttig bij de diagnose, waarbij hypoproteïnemie en hypoalbuminemie belangrijke parameters zijn. Aangevuld met een positieve serologie doet dit de kans op EPE nog meer toenemen. Toch moet hierbij een kanttekening geplaatst worden. Gezien het grote aantal seropositieve dieren, ook in de gezonde populatie, is ook deze analyse niet $100 \%$ sluitend. De meest conclusieve diagnostische test is de PCR-analyse van de mest. Hierbij zijn echter valsnegatieve resultaten mogelijk, waardoor bij sterke verdenking het PCR-onderzoek eventueel kan herhaald worden, zeker indien de patiënt serologisch positief is.

De eindconclusie is bijgevolg dat Lawsonia intracellularis hoogstwaarschijnlijk sterker verspreid is in onze paardenpopulatie dan tot op heden werd gedacht. Het klinisch beeld kan sterk variëren gaande van een verminderde conditie tot een fulminant en fataal, vlug verlopend beeld met erge diarree, hoge koorts en shocksymptomen. Daarom lijkt het momenteel zelfs aangewezen om bij veulens met acute digestieve problemen, waarbij ook een echografische zichtbare verdikking van de dunne darmwand en hypoproteïnemie aanwezig zijn, direct een therapie tegen Lawsonia in te stellen in afwachting van de bijkomende analysen. Uitstel van behandeling is in die gevallen niet aangewezen. 


\section{LITERATUUR}

Al-Ghamdi G.M., Guedes R.M., Ames T.R., Gebhart C.J. (2002). Reproduction of equine proliferative enteropathy in foals after challenge with Lawsonia intracellularis infected porcine intestinal mucosae homogenate. In: Conf Res Workers Anim Dis 2002, St-Louis, Missouri.

Atherton R.P., McKenzie H.C. (2006). Alternative antimicrobial agents in the treatment of proliferative enteropathy in horses. Journal of Equine Veterinary Science 26, 535541.

Biester H.E., Schwarte L.H. (1931). Intestinal adenoma in swine. American Journal of Pathology 7, 175-185.

Bihr T.P. (2003). Protein-losing enteropathy caused by Lawsonia intracellularis in a weanling foal. Canadian Veterinary Journal 44, 65-66.

Brees D.J., Sonhoff A.H., Kluge J.P., Andreasen C.B., Brown C.M. (1999). Lawsonia intracellularis-like organism in a miniature foal. Journal of the American Veterinary Medical Association 215, 511-514.

Breuer J., Friedrich S., Uhlig A., Schusser G.F. (2011). A follow up study on antibodies against Lawsonia intracellularis in mares and foals from two breeding farms in Germany. Berliner und Münchener Tierärztliche Wochenschrift 124, 337-342.

Breuer J., Schmoll F., Spallek A., Recknagel S., Uhlig A., Schusser G.F. (2010). Lawsonia intracellularis bei Fohlen - eine serologische Analyse. Pferdeheilkunde 26, 697-700.

Butler C.M., Nijhof A., Klarenbeek S., Meeus P., van Nieuwstadt R.A., Sloet van Oldruitenborgh-Oosterbaan M.M. (2006). Lawsonia intracellularis infection in Friesian foals. In: Proceedings Voorjaarsdagen 2006, p. 73.

Collins A., Love R.J., Pozo J., Smith S.H., McOrist S. (2000). Studies on the ex vivo survival of Lawsonia intracellularis. Swine Health and Production 8, 211-215.

Cooper D.M., Gebhart C.J. (1998). Comparative aspects of proliferative enteritis. Journal of American Veterinary Medical Association 212, 1446-1451.

Dauvillier J., Picandet V., Harel J., Gottschalk M., Desrosiers R., Jean D., Lavoie J.P. (2006). Diagnostic and epidemiological features of Lawsonia intracellularis enteropathy in 2 foals. Canadian Veterinary Journal 47, 689-691.

Deprez P., Chiers K., Gebhart C.J., Ducatelle R., Lefère L., Vanschandevijl K., Van Loon G. (2005). Lawsonia intracellularis in a 12-month-old colt in Belgium. The Veterinary Record 157, 774-776.

Drolet R., Larochelle D., Gebhart C.J. (1996). Proliferative enteritis associated with Lawsonia intracellularis (ileal symbiont intracellularis) in white-tailed deer. Journal of Diagnostic Investigation 8, 250-253.

Duhamel G.E., Wheeldon E.B. (1982). Intestinal adenomatosis in a foal. Veterinary Pathology 19, 447-450.

Ellis A.E., Kelsey A.H., Elfenbein J.R. (2011). Pathology in practice. Journal of the American Veterinary Medical Association 238, 1417-1419.

Frank N., Fishman C.E., Gebhart C.J., Levy M. (1998). Lawsonia intracellularis enteropathy in a weanling foal. Equine Veterinary Journal 30, 549-552.

Frazer M.L. (2008). Lawsonia intracellularis infection in horses: 2005-2007. Journal Veterinary Internal Medicine 22, 1243-1248.

Guedes M.C.R., Gebhart C.J., Winkelman N.L., MackieNuss R.A.C., Marsteller T.A., Deen J. (2002). Comparison of different methods for diagnosis of porcine proliferative enteropathy. Canadian Journal of Veterinary Research 66, 99-107.

Klein E.C., Gebhart C.J., Duhamel G.E. (1999). Fatal outbreaks of proliferative enteritis caused by Lawsonia intracellularis in young colony raised rhesus macaques. Journal of Medical Primatology 28, 11-18.

Klimes J., Dezorzova K., Smola J., Husnik R. (2007). Prevalence of antibodies against Lawsonia intracellularis in dogs with and without gastrointestinal disease. Veterinarni Medicina 52, 502-506.

Kranenburg L.C., van Ree H.E.M.I., Calis A.N.M., de Pater M., Butler G.J., van Maanen C., Sloet van OldruitenborghOosterbaan M.M. (2011). The seroprevalence of Lawsonia intracellularis in horses in the Netherlands. Tijdschrift voor Diergeneeskunde 136, 236-243.

Lavoie J.P., Drolet R., Parsons D., Leguillette R., Sauvageau R., Shapiro J., Houle L., Hallé G., Gebhart C.J. (2000). Equine proliferative enteropathy: a cause of weight loss, colic, diarrhoea and hypoproteinaemia in foals on three breeding farms in Canada. Equine Veterinary Journal 32, 418-425.

Lawson G.H.K., Gebhart C.J. (2000). Proliferative enteropathy. Journal of Comparative Pathology 122, 77-100.

McClintock S.A., Collins A.M. (2004). Lawsonia intracellularis proliferative enteropathy in a weanling foal in Australia. Australian Veterinary Journal 82, 750-752.

McGurrin K.J.M., Vengust M., Arroyo L.G., Baird J.D. (2007). An outbreak of Lawsonia intracellularis infection in a standardbred herd in Ontario. Canadian Veterinary Journal 48, 927-930.

McKenzie H.C. (2009). Equine proliferative enteropathy: Lawsonia intracellularis. In: Mair T.S. and Hutchinson R.E (editors). Infectious Diseases in Horses. $1^{\text {st }}$ Ed., Geerings print Ltd, Kent, UK, p.199-207.

McOrist S., Gebhart C.J., Boid R., Barns S.M. (1995). Characterization of Lawsonia intracellularis gen. nov., sp. nov., the obligately intracellular bacterium of porcine proliferative enteropathy. International Journal of Systematic Bacteriology 45, 820-825.

Merlo J.L., Sheats M.K., Elce Y., Hunter S., Breuhaus B.A. (2009). Outbreak of Lawsonia intracellularis on a Standardbred farm in North Carolina. Equine Veterinary Education 21, 179-182.

Nogradi N., Slovis N.M., Gebhart C.J., Wolfsdorf K.E., McCracken J.L., Scoggin C.F., Kass P.H., Mapes S.M., Toth B., Lundquist M.L., Pusterla N. (2011). Evaluation of the field efficacy of an avirulent live Lawsonia intracellularis vaccine in foals. The Veterinary Journal (in press).

Page A.E., Slovis N.M., Gebhart C.J., Wolfsdorf K., Mapes S.M., Pusterla N. (2011). Serial use of serologic assays and fecal PCR assays to aid in identification of subclinical Lawsonia intracellularis infection for targeted treatment of Thoroughbred foals and weanlings. Journal of the American Veterinary Medical Association 238, 1482-1489.

Pusterla N., Gebhart C. (2009). Equine proliferative enteropathy caused by Lawsonia intracellularis. Equine Veterinary Education 21, 415-419.

Pusterla N., Hilton H., Wattanaphansak S., Collier J.R., Mapes S.M., Stenbom R.M., Gebhart C. (2009). Evaluation of the humoral immune response and fecal shedding in weanling foals following oral and intra-rectal administration of an avirulent live vaccine of Lawsonia intracellularis. The Veterinary Journal 182, 458-462.

Pusterla N., Jackson R., Wilson R., Collier J., Mapes S., Gebhart C. (2009). Temporal detection of Lawsonia intracel- 
lularis using serology and real-time PCR in Thoroughbred horses residing on a farm endemic for equine proliferative enteropathy. Veterinary Microbiology 136, 173-176.

Pusterla N., Mapes S., Rejmanek D., Gebhart C. (2008). Detection of Lawsonia intracellularis by Real-time PCR in the feces of free-living animals from equine farms with documented occurrence of equine proliferative enteropathy. Journal of Wildlife Diseases 44, 992-998.

Pusterla N., Wattanaphansak S., Mapes S., Collier J., Hill J., Di Francesco M., Gebhart C. (2010). Oral infection of weanling foals with an equine isolate of Lawsonia intracellularis, agent of equine proliferative enteropathy. Journal of Veterinary Internal Medicine 24, 622-627.

Reef V.B. (1998). Pediatric abdominal ultrasonography. In: Equine diagnostic ultrasound. $1^{\text {st }}$ ed., W.B. Saunders, Philadelphia, p. 364-403.

Sainty T.J. (2002). Proliferative enteritis caused by Lawsonia intracellularis infection. Proceedings of the BEVA Congress, Glasgow, UK, 2002, p 48.

Sampieri F., Hinchcliff K.W., Toribio R.E. (2006). Tetracycline therapy of Lawsonia intracellularis enteropathy in foals. Equine Veterinary Journal 38, 89-92.

Schumacher J., Schumacher J., Rolsma M., Brock K.V., Gebhart C.J. (2000). Surgical en medical treatment of an Arabian filly with proliferative enteropathy caused by Lawsonia intracellularis. Journal of Veterinary Internal Medicine 14, 630-632.

Smith D.G.E., Lawson G.H.K. (2001). Lawsonia intracellularis: getting inside the pathogenesis of proliferative enteropathy. Veterinary Microbiology 82, 331-345.

Smith S.H., McOrist S. (1997). Development of persistent intestinal infection and excretion of Lawsonia intracellularis by piglets. Research in Veterinary Science 62, 6-10.

Van den Wollenberg L., Butler C.M., Houwers D.J., de Groot M.W., Panhuijzen H., van Maanen C., Sloet van Oldruitenborgh-Oosterbaan M.M. (2011). Lawsonia intracellularis-associated proliferative enteritis in weanling foals in the Netherlands. Tijdschrift voor Diergeneeskunde 136, 565-570.

Westhoff D., Kissel C., Schuon C. (2010). Lawsonia intracellularis Erkrankungen beim Pferd - auch in Deutschland ein Problem? Erste Verträglichkeitdaten eines Impfstoffes bei Fohlen. Praktischer Tierarzt 91, 316-325.

Williams N.M., Harrison L.R., Gebhart C.J. (1996). Proliferative enteropathy in a foal caused by Lawsonia intracellularis-like bacterium. Journal of Veterinary Diagnostic Investigation 8, 254-256.

Wong D.M., Alcott C.J., Sponseller B.A., Young J.L., Sponseller B.T. (2009). Impaired intestinal absorption of glucose in 4 foals with Lawsonia intracellularis infection. Journal of Veterinary Internal Medicine 23, 940-944.

Wuersch K., Huessy D., Koch C., Oevermann A. (2006). Lawsonia intracellularis proliferative enteropathy in a filly. Journal of Veterinary Medicine 53, 17-21. 